\title{
The Changing Landscape of RTAs and PTAs: Analysis and Implications
}

\section{Rashid S. Kaukab*}

\begin{abstract}
This paper traces the evolution of "discriminatory" international trading arrangements: (i) regional trade agreements (RTAs), which offer their members better access to each other's markets; and (ii) preferential trade agreements (PTAs), which offer developing and least developed countries (LDCs) nonreciprocal access to certain markets. The number, coverage, and depth of RTAs have increased tremendously in the last 25 years, potentially leading to even deeper integration among dynamic economies. However, countries on the margin of RTA activity may be in danger of not benefitting from the growth in international trade. The number of countries offering PTAs has also increased with many developing countries now providing LDCs with nonreciprocal market access. This significant level of RTA and PTA activity raises serious challenges for countries such as Pakistan, which remain on the margins. Efforts to rectify this should, in the short term, focus on negotiating RTAs with selected countries to build the required capacity for such negotiations and improve Pakistan's visibility on the RTA landscape. The country must aggressively seek and defend nonreciprocal market access under PTAs, with particular focus on such GSP schemes as offer additional benefits. Medium-term actions should aim to improve competitiveness by investing in infrastructure, energy, and human resources; adopting a coherent and supportive macroeconomic policy framework; and improving law and order. This will help Pakistan enter into and benefit from RTAs with dynamic economies while substantially reducing its dependence on PTAs.
\end{abstract}

Keywords: Pakistan, WTO, regional trade agreements, preferential trade agreements, GSP.

JEL classification: F13, F40.

\footnotetext{
* Director, Consumer Unity and Trust Society (CUTS) International, Geneva, Switzerland. The author is grateful to Dr Irfan ul Haq for giving him the opportunity and to Anna Brezheneva and Matthias Maltha of the Graduate Institute in Geneva for their valuable research assistance.
} 


\section{Introduction}

Global trade governance has evolved substantially in the last 25 years. With the establishment of the World Trade Organisation (WTO) in the mid-1990s, a comprehensive set of binding and enforceable agreements came into force, spanning more than 100 countries and customs territories, and covering most world trade flows (at least of goods). This was a major achievement for nondiscriminatory trade. ${ }^{1}$ The world seemed to be moving toward an overarching, global, and nondiscriminatory framework that would eventually cover all countries (through their accession to the WTO) and all aspects of trade (through negotiations among WTO members for the further liberalization of trade in goods and services and development of all the required and related rules).

This has not happened, however. Instead, discriminatory trade agreements (DTAs) ${ }^{2}$ have proliferated while the WTO Doha Round of trade negotiations has languished for over 12 years. The increasing number and scope of DTAs is fast reshaping the architecture of the world trading system and the trading environment for developing countries. This is particularly relevant for countries such as Pakistan, which are not party to many DTAs. Moreover, the integration of these diverse agreements into a multilateral framework that facilitates the expansion of trade on beneficial terms for all is one of the main challenges facing the world trading system.

This paper is an attempt to better understand the trend of DTAs over the last 25 years while drawing lessons for Pakistan. For the purposes of this analysis, we divide all DTAs into two broad categories: (i) those based on reciprocity among their members, i.e., regional trade agreements (RTAs); ${ }^{3}$ and (ii) those under which one country or defined

\footnotetext{
${ }^{1}$ WTO members have to abide by the principle of nondiscrimination by granting similar trade privileges to all other members (the so-called most-favored nation treatment). This remains a key foundation of the multilateral trading system represented by the WTO, although certain exceptions are allowed, the most important being regional and preferential trade arrangements.

${ }^{2}$ This paper defines DTAs as all those agreements that are among a small number of WTO members outside the WTO and which provide their members with better trade treatment than they might receive under the WTO, without offering it to all WTO members. Hence, DTAs are categorized as "discriminatory" toward nonmembers as opposed to the "nondiscriminatory" nature of WTO agreements.

${ }^{3}$ RTAs include free trade agreements, customs unions, and economic unions among two or more countries within the same region or across regions.
} 
group of countries offers nonreciprocal trade preferences to another, i.e., preferential trade agreements (PTAs). ${ }^{4}$

Given the depth and breadth of the subject, this paper cannot claim to be comprehensive and exhaustive. Rather, it aims to provide an overall picture and broad-brush analysis to facilitate discussion and further targeted research. Sections 2 and 3 analyze the evolution of RTAs and PTAs, respectively. We trace key developments in both over the last 25 years or so, leading up to the present and identifying the main players, beneficiaries, features, and trends. Section 4 briefly discusses the so-called "mega-regionals," i.e., the proposed Trans-Pacific Partnership (TPP) and Transatlantic Trade and Investment Partnership (T-TIP). Section 5 highlights the specific implications of RTAs and PTAs for Pakistan and then concludes the study by offering some policy suggestions.

\section{RTAs: Beyond Numbers 5}

As of 31 July 2013, the General Agreement on Tariffs and Trade (GATT)/WTO has received some 575 RTA notifications (counting goods, services, and accessions separately) (WTO, 2014). Of these, 408 notifications were made under Article XXIV of GATT 1947 or GATT 1994, 38 under the Enabling Clause, and 129 under Article V of the General Agreement on Trade in Services. Of these 575 RTAs, 379 were in force at the time.

However, the number of RTAs in force at the time of writing is 278 (Figure 1). In addition to bringing out the general difficulty of counting and tracking RTA activity precisely, this brings home a very important point. Not all announced RTAs see the light of day. Only about half complete the negotiations stage, reach a final agreement, undergo domestic ratification, and are finally implemented by the participants. While the WTO can rightly be faulted for slow progress, the record of RTAs is not a shining example of success either.

Looking at the number of RTAs notified and entered into force over time is fairly instructive. As Figure 2 shows, RTAs became

\footnotetext{
${ }^{4}$ The WTO defines PTAs as all such arrangements that include, for example, the Generalized System of Preferences schemes of various developed countries for all eligible developing countries, and specialized preferential trade schemes targeting a defined group of beneficiaries (such as least developed countries). The main feature of such schemes is nonreciprocity: the trade concessions offered do not seek trade preferences in return.

${ }^{5}$ Unless otherwise specified, the data and figures in this section are derived from or based on the WTO's Regional Trade Agreements Information System (see WTO, 2014).
} 
increasingly common in the early 1990s when an unusually high number of agreements entered into force-26 between 1990 and 1994 alone, compared to just 24 up until 1990. The number of RTA notifications continued to increase in the second half of the 1990s. The mid-2000s onward saw the largest number of RTAs notified and coming into force to date. In particular, 28 RTAs were notified in 2008 alone. Despite a subsequent dip in notifications in 2009-11, the number of RTAs has begun to increase once again.

\section{Figure 1: Agreements notified and in force}

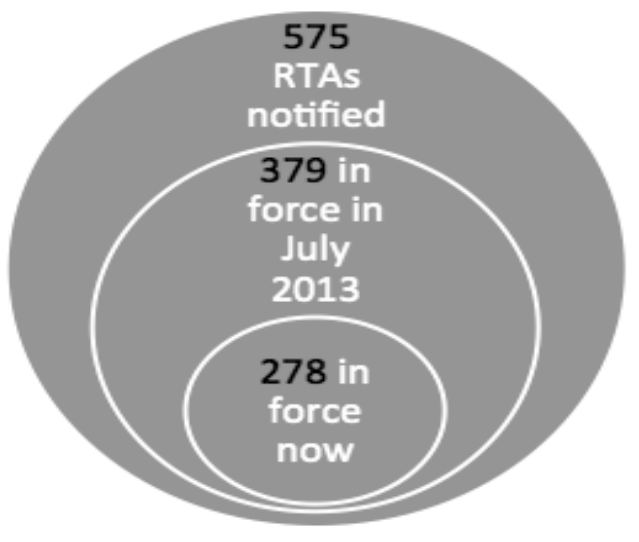

Figure 2: RTAs notifications and entry into force over time

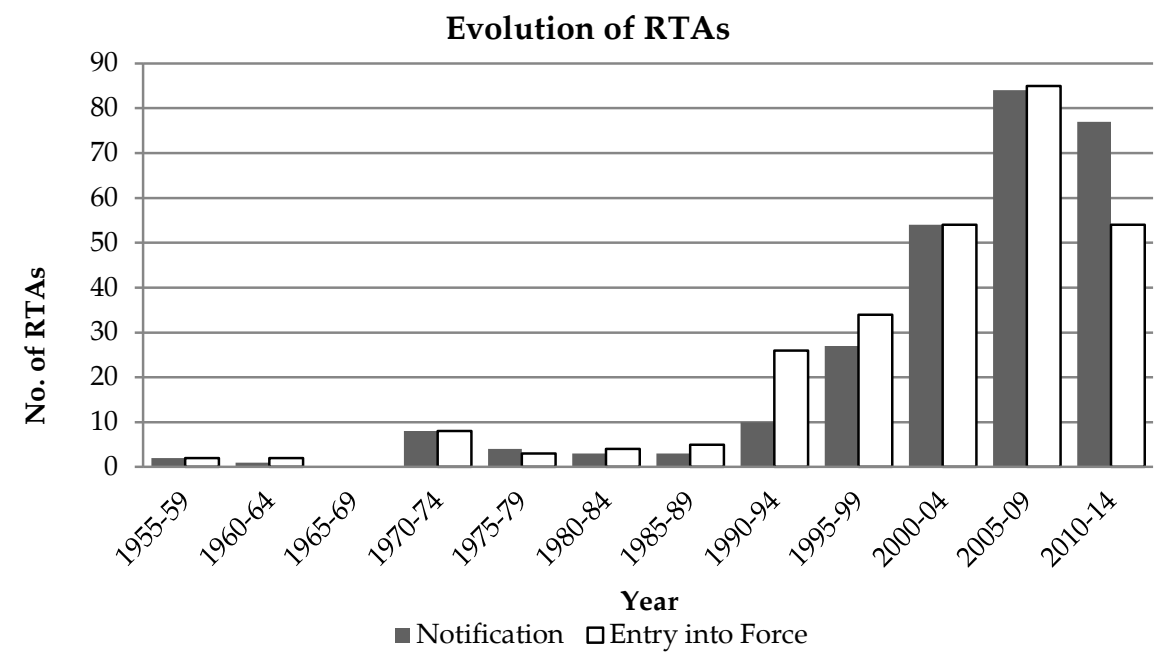

One can safely conclude that the spurt in RTAs occurred in the early 1990s and has since maintained an upward trend in general. 
Interestingly, the early 1990s also witnessed the conclusion of the Uruguay Round and the emergence of the WTO-a key achievement for multilateralism. These twin developments do not support the contention that multilateral agreements and RTAs are substitutes for one another, i.e., that one moves forward if and when the other is stalemated. Both made remarkable progress in the 1990s, but while RTAs remained on this trajectory, WTO multilateralism did not advance much farther.

This means that multilateralism can coexist with regionalism, with both "moving" forward but not at the expense of each other. However, the "pace of movement" of one may affect that of the other. In this more nuanced view, if one is stalemated-as the WTO Doha Development Agenda (DDA) has been-pressure increases on the other. However, even when the stalemate in one is broken (as the WTO Bali ministerial conference of December 2013 seems to have done for the DDA), the other may continue to move, albeit perhaps at a slower pace.

The breadth of liberalization and depth of integration among members of an RTA depend on whether it is a partial scope agreement (PSA) covering only some goods, a free trade agreement (FTA) essentially covering substantial trade in goods, or a customs union (CU) where members of the agreement also adopt a common external tariff toward nonmembers. The RTAs listed in the WTO database indicate that the majority in force are FTAs ( 83 percent), followed by CUs (11 percent), while PSAs are the least common (Figure 3). Looking at the type and membership of RTAs, one notes that those between developing countries more often tend to be PSAs, while developed countries generally conclude FTAs and are more likely to be part of a CU (though this conclusion is heavily influenced by the European Union [EU]).

Figure 3: Types of RTAs worldwide (in force in early 2014)

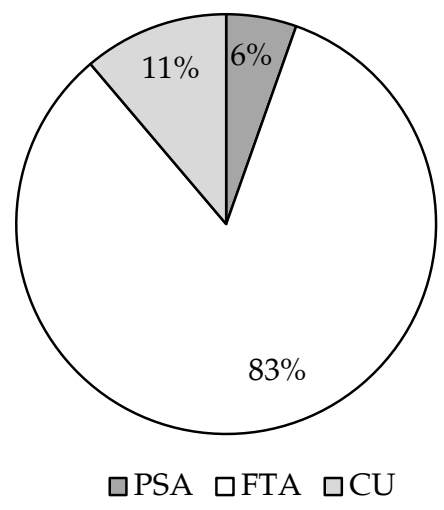


The major zones of RTA activity are concentrated in the Global North, with the EU being a major RTA participant, followed by the US. The exceptions to this are Chile and Peru, both of which have a substantial number of agreements comparable with those of the US and EU. Both countries are members of the Latin American Integration Association and have numerous bilateral agreements with countries in and outside the region (with a significant proportion of these being with Asian countries). The African continent, the Middle East and, to some extent, Central Asia have the lowest RTA participation. In Africa, despite the existence of many regional organizations-the Economic Community of West African States (ECOWAS), the Economic Commission for Africa, the Southern African Development Community (SADC), and so onbilateral agreements are practically nonexistent. North Africa is, however, an exception, with some countries that have agreements with the EU and/or Turkey.

Besides the Commonwealth of Independent States (CIS), the Eurasian Economic Community, and the Common Economic Zone (of which, among the Central Asian countries, only Kazakhstan is a member), Central Asia lacks RTAs, though most countries have bilateral agreements with each other. The Middle Eastern countries participate in a limited number of RTAs-namely, the Pan-Arab Free Trade Area and the Gulf Cooperation Council-but similar to the situation in Africa, they lack bilateral agreements both with each other and with countries outside the region.

Figures 4 and 5 capture the dramatic change in worldwide RTA activity between 2013 and 1995, respectively. In 1995, Western Europe had already begun to emerge as the key region in terms of RTA activity. The countries with the highest number of RTAs were European Community (EC) members with 16 agreements each. Most of these were bilateral agreements with other European countries, which, by 2013, had become EU members themselves (such as Andorra, the Czech Republic, and Poland). This also included European countries that would not join the EU but formed the European Free Trade Association (EFTA), including Switzerland, Norway, Liechtenstein, and Iceland. The EC's RTAs outside Europe were limited to three: with the Overseas Countries and Territories, Syria, and Lebanon.

Russia's participation during this period also seems relatively significant, particularly compared to 2013. However, it should be noted that, in 1995, Russia was ahead because of the multiple agreements it 
concluded with the former Soviet republics; these agreements remain largely unchanged to this day. Besides the addition of the CU between Belarus, Russia, and Kazakhstan, there were no significant developments in terms of RTAs within the CIS after 1995.

The involvement of African and Central Asian countries was as sparse in 1995 as it is now. No bilateral agreements existed between any African countries-only regional agreements such as the Common Market for Eastern and Southern Africa (COMESA) and ECOWAS. This also corresponds to present-day RTA participation among countries in Africa: bilateral agreements remain fairly rare. The Americas as a whole were relatively inactive in terms of RTA participation at the start of 1995 . The Latin American countries, many of which now have a significant number of RTAs under their belt, had yet to emerge in that sense. So, too, did Asia, in particular the Association of South East Asian Nations (ASEAN)+3 (China, Japan, and the Republic of Korea).

Figure 4: RTAs per country in force in 2013

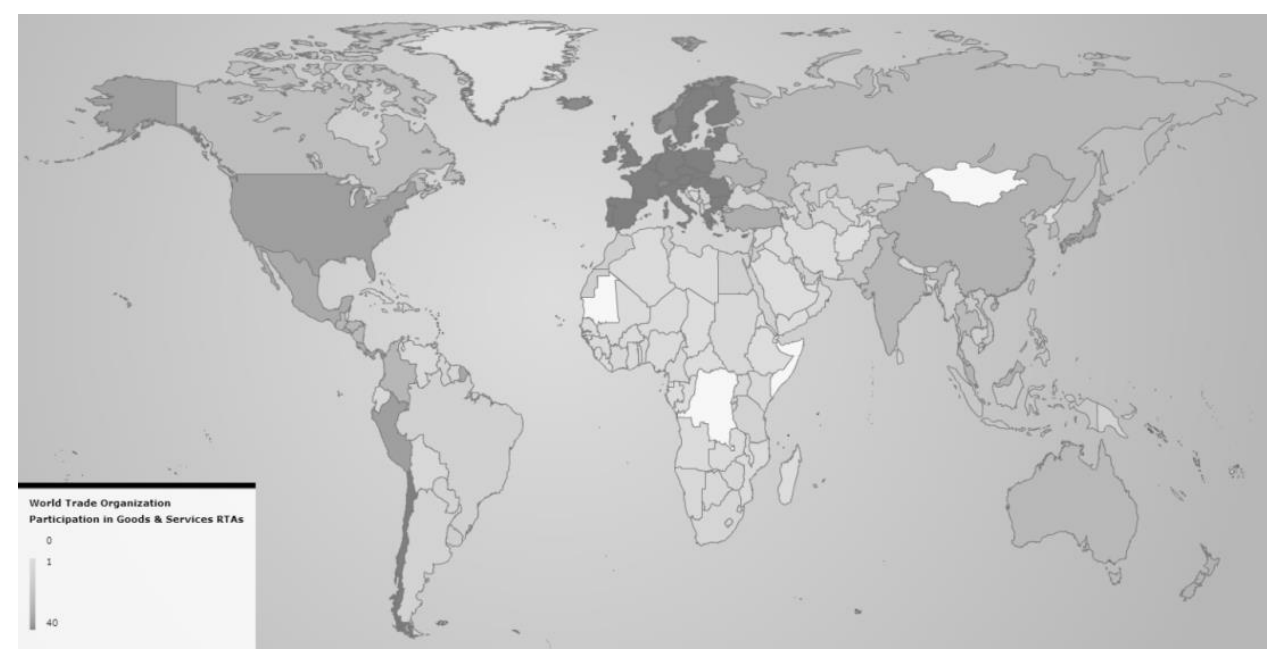

Source: http://www.wto.org/english/tratop_e/region_e/rta_participation_map_e.htm] 
Figure 5: RTAs per country in force in 1995

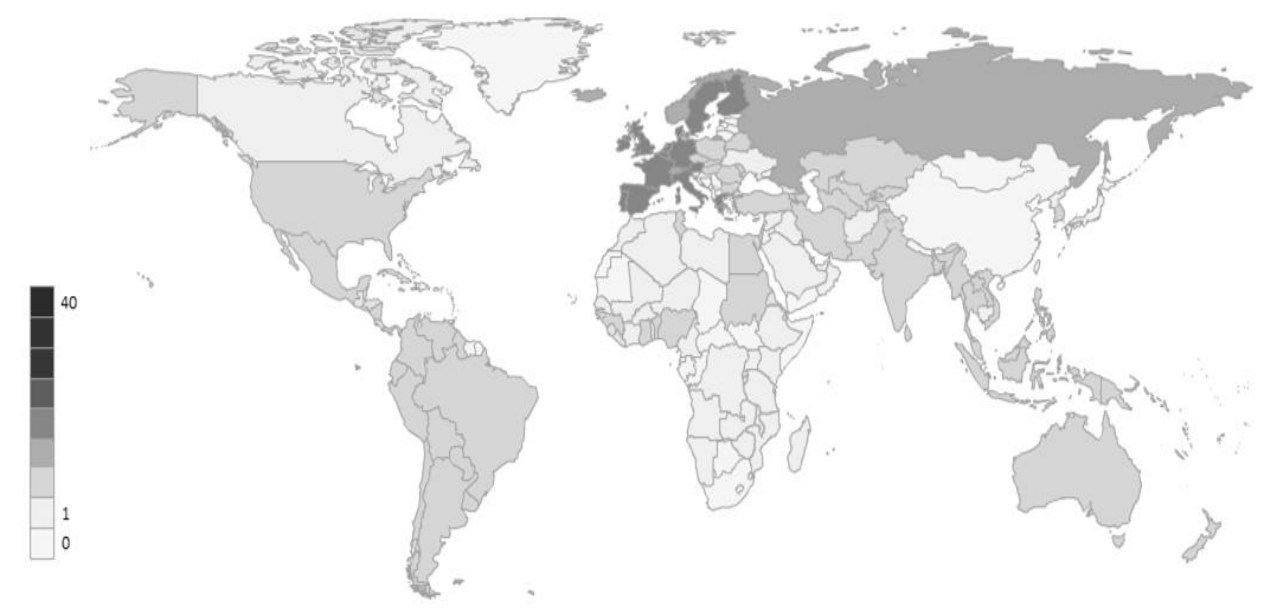

Source: Constructed using WTO and World Bank databases.

As a whole, RTAs pre-1995 applied predominantly to intraregional trade: the expansion of the EC, the creation of the North American Free Trade Agreement (NAFTA) and Caribbean Community (CARICOM), and other regional agreements. Inter-regional agreements were few: aside from the agreement between the US and Israel, no other inter-regional bilateral agreement existed where one of the parties was not an RTA member (i.e., bilateral agreements between two countries from different regions). As Figure 6 shows, there was a dramatic increase in FTAs (nearly sevenfold) between 1995 and 2013, whereas the change in PSAs and CUs was smaller (both roughly doubled).

Figure 6: RTAs in 1995 vs. 2013

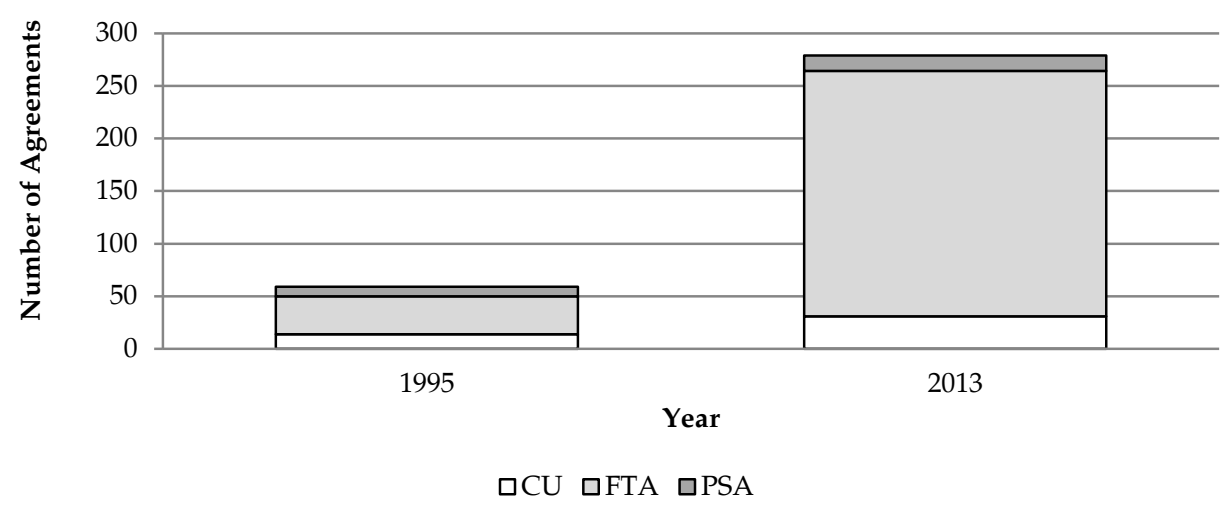


An important question that arises with the proliferation of RTAs, their types, and membership, is whether the world is being divided into blocs. In such a scenario, bigger countries would be seen constructing their respective blocs both within the region and outside. RTA activity with countries outside these blocs would be limited, though one would also see some agreements among the blocs. On taking a closer look, however, this does not seem to be happening.

The EU is currently at the centre of RTA activity, both in terms of the number of agreements it has concluded and is negotiating, and in terms of their geographical spread. It also seems to be negotiating a great deal and is looking to replace bilateral agreements as well as nonreciprocal trade arrangements with more comprehensive agreements with other regional organisations. For example, the EU has signed comprehensive, reciprocal economic partnership agreements with the CARICOM and ECOWAS countries to replace its longstanding nonreciprocal trade relationship with them. Hence, there is no evidence that the EU is constructing an inward-looking trading bloc with defined boundaries.

Similarly, US agreements are predominantly intra-regional as are those in Eastern Europe and Central Asia-with the exception of the former Soviet republics, which seem to be concluding agreements only among themselves. The African continent has a number of overlapping regional organizations but lacks bilateral connections, especially with countries outside the region. In Asia, ASEAN+3 is the most significant RTA, with some bilateral agreements outside the region. Japan, China, India, Singapore, and the Republic of Korea have the highest number of agreements. India, however, only has agreements with developing countries and emerging economies.

Figure 7 illustrates the more recent RTA activity to further explore the emergence or otherwise of RTA blocs. As mentioned earlier, RTAs mushroomed a second time from 2008 onward. During this period, there was a dramatic increase in FTAs (89), with a couple of CUs and a very small number of PSAs (three). The substantial majority of agreements now include both goods and services. 
Figure 7: Country by number of RTAs entering into force 2008 onward

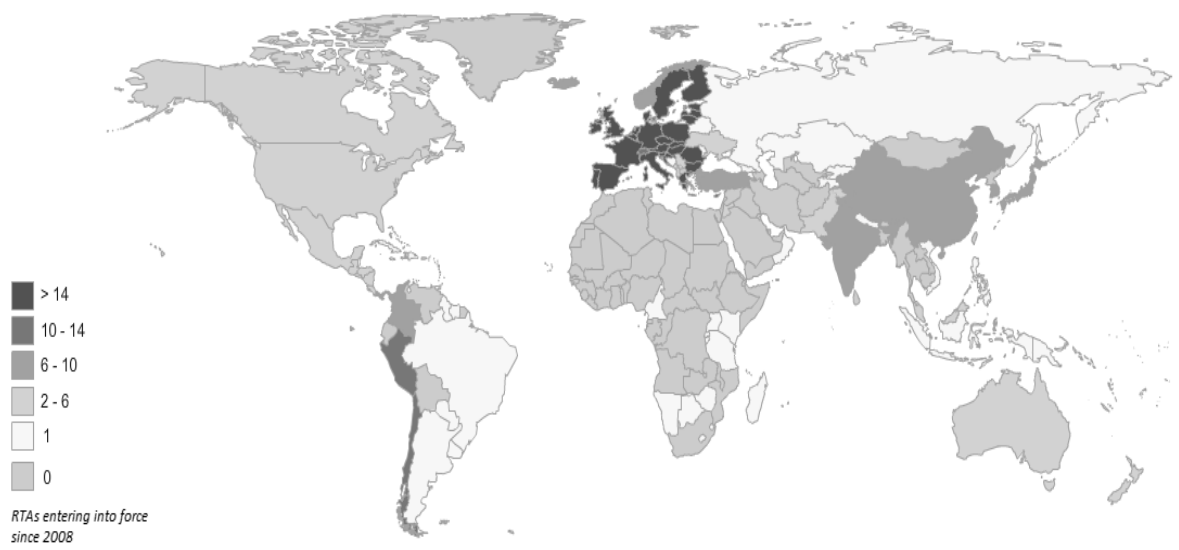

A number of existing RTA parties, in particular ASEAN, EFTA, and the EU, also concluded numerous bilateral agreements from 2008 onward with countries outside their immediate region. The EU's bilateral agreements tend to be with the Balkans, the African continent, Latin America, and the Asia-Pacific. EFTA's agreements are also with the Balkans, the Asia-Pacific, and Latin America; this is not surprising as EFTA countries have to maintain parity with the EU in their international trade relations, given the two blocs' very close trade and economic relationship. ASEAN agreements lie primarily within the Asia-Pacific.

The world's main single-country players include Peru, Chile, Panama, Japan, China, the Republic of Korea, and India. In particular, countries in Latin America and Asia have concluded several bilateral RTAs (e.g., Chile and Malaysia, Chile and China, Peru and China, Costa Rica and Singapore). Bilateral RTAs have developed most notably in (and between) Latin America and the Asia-Pacific. In contrast, there were almost no new agreements among countries in Africa and the Middle East.

A tentative conclusion from this complex and evolving picture is that, although the EU remains a highly dynamic region, the world is not necessarily splitting off into blocs. There is still a substantial degree of inter-bloc activity as well as several individually active countries, particularly in Latin America and the Asia-Pacific. 


\section{PTAs: Who is Offering Preferences to Whom? ${ }^{6}$}

Nonreciprocal trading arrangements (PTAs), whereby one country or RTA provides better market access to other designated countries without asking for trade preferences in return, are also fairly common. Together with RTAs, PTAs comprise the universe of so-called discriminatory trade. Hence, it is equally important to examine PTAs to complete our analysis of the global trade arrangements confronting countries such as Pakistan.

The number of PTAs surged in the 1970s, spurred mainly by the work carried out by the United Nations Conference on Trade and Development (UNCTAD). This led to the emergence of the General System of Preferences (GSP) whereby developed countries could offer developing countries nonreciprocal trade preferences. GATT's Enabling Clause, adopted as part of the Tokyo Round, provided the legal cover for this, driving the process further. While GSP schemes were generally available to all developing countries, the 1980s marked the beginning of PTAs that were designed for specific subgroups of developing countries, often on a regional basis. These included PTAs by some developed countries for developing countries from the Caribbean, Pacific, and Andean regions.

The second surge in PTAs occurred around the turn of the $21^{\text {st }}$ century. This period has so far proven to be the most productive in terms of PTAs entering into force with 11 new global players and two different types of schemes. ${ }^{7}$ The surge has several interesting new features (see Figures 8 and 9). First, it is characterized by the rise of emerging economies/developing countries as providers of PTAs alongside developed countries. ${ }^{8}$ Second, many PTAs benefitting only LDCs have been introduced. This was made possible by amending the Enabling Clause to allow GSP sub-schemes that benefitted the LDCs in recognition of their extreme levels of underdevelopment. Third, new PTAs for specific regions have entered into force, i.e., for the western Balkans and the sub-Saharan African countries, respectively, by the EU and US. Fourth, the regional composition of providers has changed. Although

\footnotetext{
${ }^{6}$ Unless otherwise specified, the data for this section has been derived from the WTO's Database on Preferential Trade Agreements (see WTO, n.d.).

${ }^{7}$ Overall, 26 PTAs have entered into force since 1948.

${ }^{8}$ Three GSP schemes have been introduced since the beginning of the century: by Iceland, Turkey and the Russian Federation, and Belarus and Kazakhstan.
} 
European countries remain the biggest providers, countries from Asia and the CIS have offered more PTAs than North America in this time. Similarly, both Africa and the CIS have initiated PTAs during this period.

Figure 8: Evolution of PTAs, 1945-2014: GSP/LDC-specific and other schemes entering into force

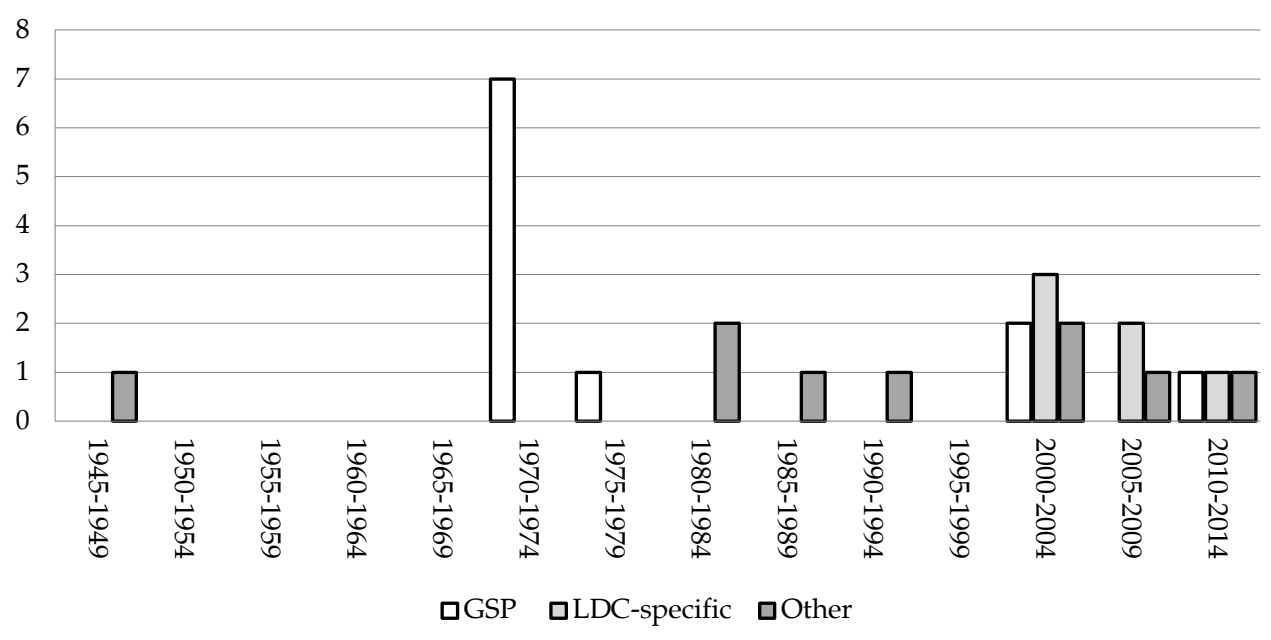

Figure 9: Evolution of PTAs, 1945-2014: Providers

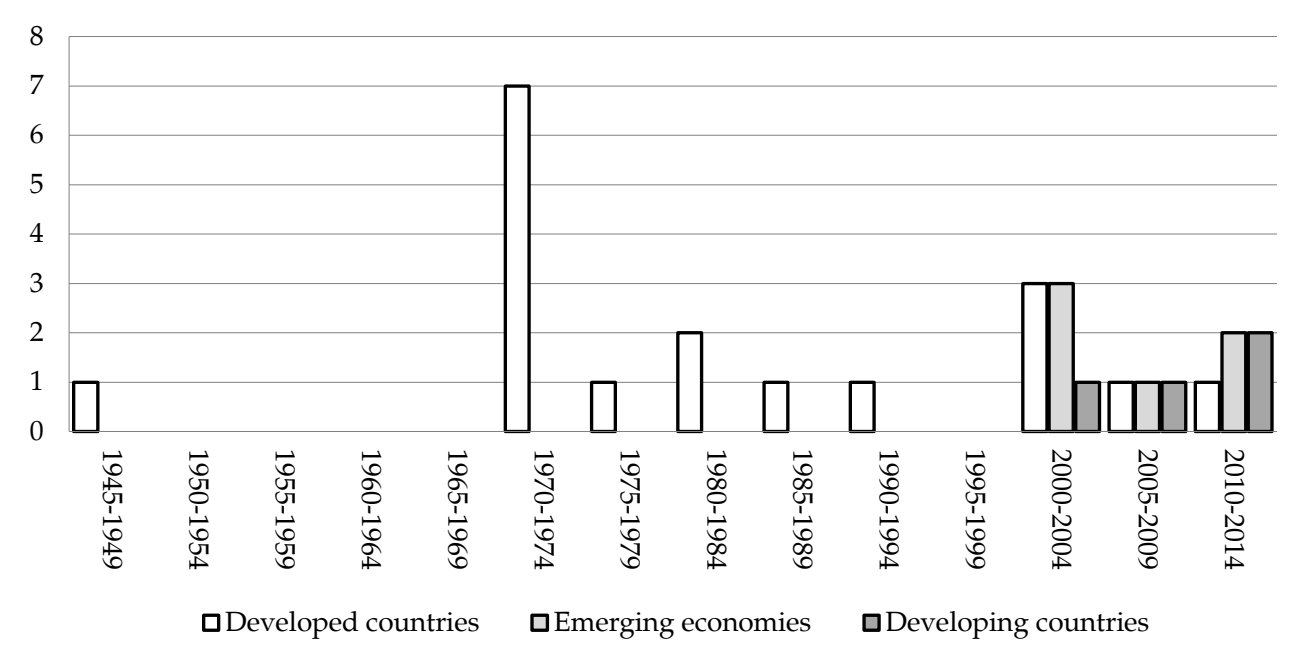

Looking at the current situation, there is a clear distinction between the role of developed countries and that of the emerging economies or developing countries offering PTAs (Figure 10). While no developed country is a PTA beneficiary, all the emerging economies/developing countries that serve as providers are also beneficiaries. Those leading the 
ranks of providers among the major developed countries are the US and EU, which offer, respectively, five and four PTAs. A brief analysis shows that all GSP schemes offer unilateral differential trade preferences for LDCs, except for Iceland's GSP scheme. ${ }^{9}$ On the other hand, the sole GSPplus providers are the EU and Norway, ${ }^{10}$ although the EU's beneficiaries have yet to be notified following the implementation of the new GSP-plus regulations in January 2014.

Figure 10: PTA providers and/or beneficiaries

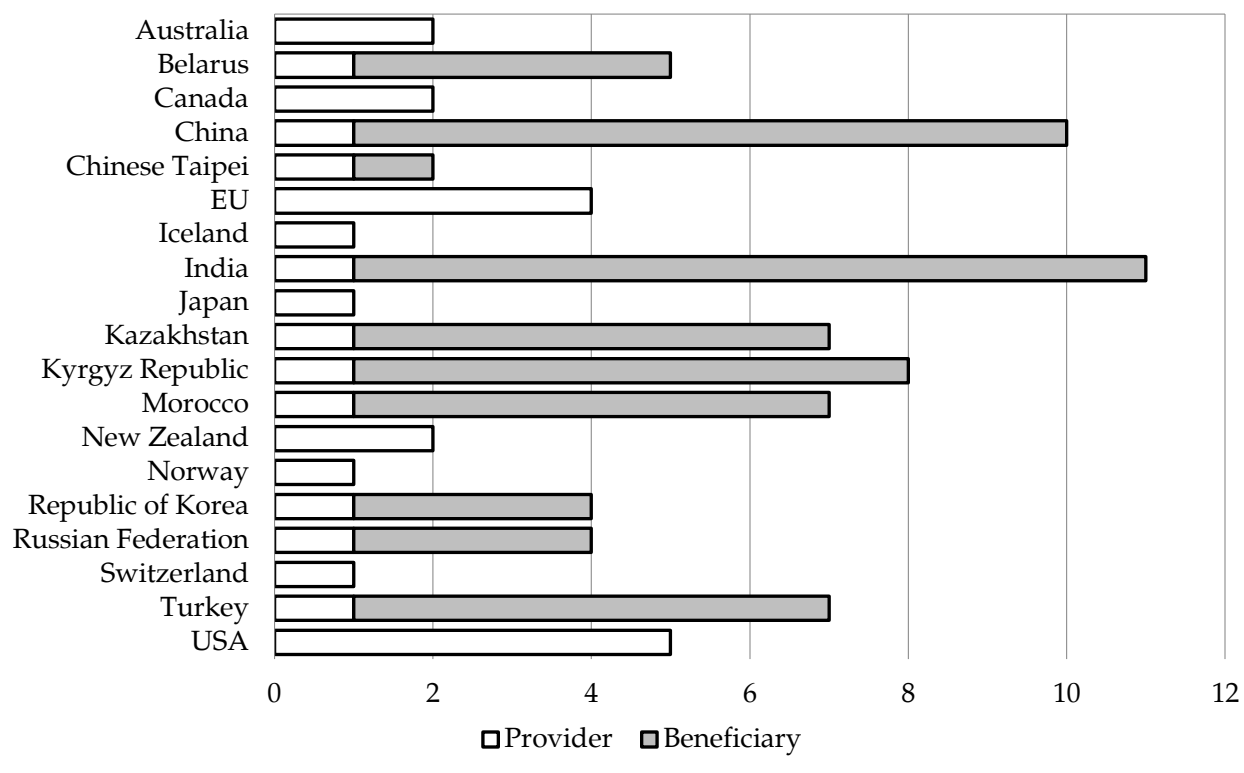

With respect to GSP beneficiaries from a regional perspective, the top three regions are the Americas and the Caribbean, Asia, and Africa. Overall, the smallest beneficiaries are the Middle East, the CIS, and Europe. Africa's GSP benefits greatly augment its substantial coverage under LDC-specific sub-schemes, from which the region benefits extensively in comparison to Asia, the Americas and the Caribbean, the Middle East, and the CIS. Among LDC-specific trade preference schemes, India's is considerably smaller than that of the others, while the Kyrgyz Republic and the Republic of Korea might be considered the top providers in terms of the number of beneficiary LDCs.

\footnotetext{
${ }^{9}$ Since Iceland does not differentiate between developing countries and LDCs, the latter fall under its "normal" GSP scheme.

${ }^{10}$ Note that Norway's beneficiaries listed on the WTO PTA database website reflect only the GSPplus and LDC beneficiaries. Its own website also mentions the "normal" GSP beneficiaries.
} 
On a global scale, it is clear that PTA provision is no longer the sole realm of developed countries such as the US, Japan, and Australia. Increasingly, emerging economies are joining the ranks, although of the group Brazil, Russia, India, China, and South Africa (BRICS), Brazil and South Africa are still missing. So far, only Morocco has stepped up as a PTA provider in Africa, with China and India in the Asian region. Emerging/developing country providers are still absent from Central and South America and the Caribbean. In terms of beneficiaries, the LDC group has attracted benefits under numerous PTAs (Figure 11). Of the 49 LDCs, 32 benefit from more than 15 PTAs each. In Europe, it is predominantly the western Balkans (with Turkey as the odd one out) that receive trade preferences from PTA providers.

Figure 11: The nature of PTAs, providers, and beneficiaries

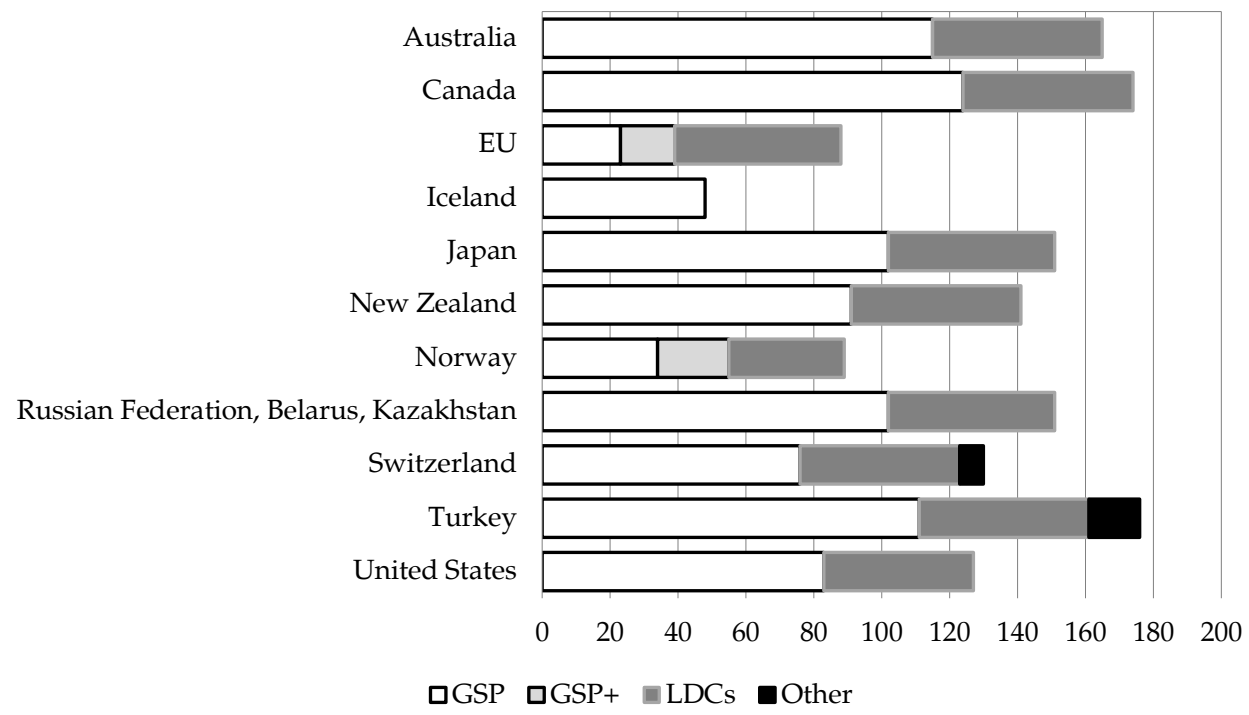

Note: Includes countries that were eligible for the EU's GSP-plus status in July 2013.

In terms of particular relationships between providers and beneficiaries, it is interesting to see that the EU has the least number of African GSP beneficiaries despite their apparent historical connections. However, this could be explained by the fact that the EU has been reformulating its trading relationship with members of the African, Caribbean, and Pacific Group of States by signing economic partnership agreements that offer preferences similar to the GSP scheme but on a reciprocal basis. Moreover, the EC also offers substantial preferences to African LDCs under its Everything-But-Arms scheme (designed specifically for LDCs). 
Figure 12 shows the distribution of beneficiaries based on the number of PTAs from which they benefit. Not surprisingly, most of the African and Asian LDCs are in the topmost group with more than 15 PTAs in their favor. Pakistan is in the second bracket, which benefits from 11-15 PTAs and includes countries such as Myanmar, Yemen, the Republic of the Congo, the Democratic Republic of the Congo, Guyana, and Ecuador. Figure 13 shows that, despite the recent increase in the number of PTA providers, the US and EU remain the main players in terms of the number of PTAs they offer, followed by other major developed countries such as Canada and Australia.

Figure 12: PTA beneficiaries by number of PTAs

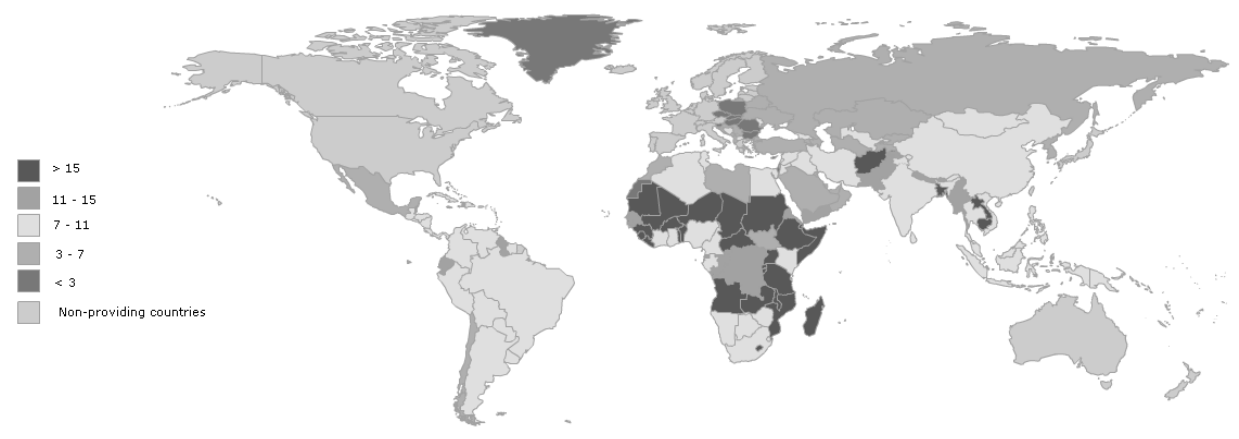

Figure 13: PTA providers by number of PTAs offered

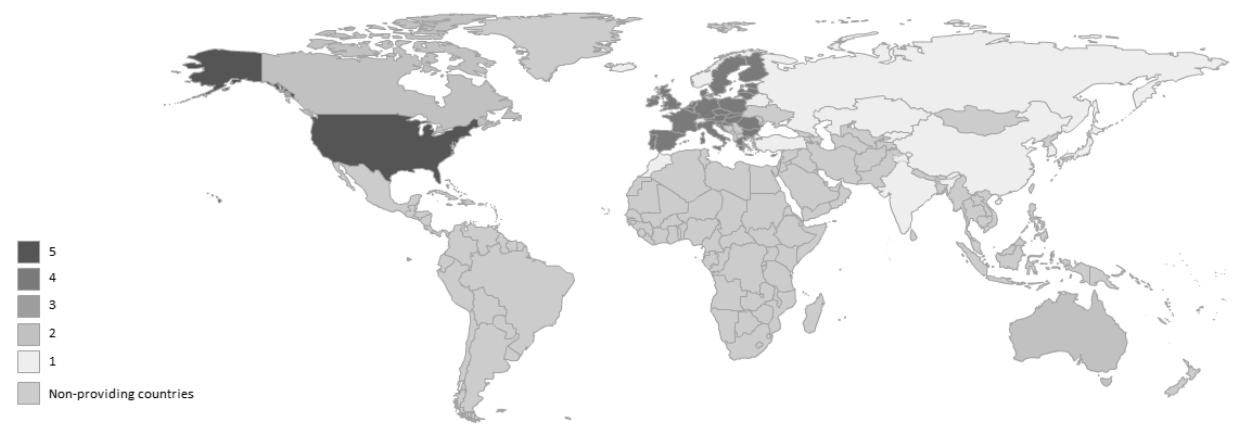

4. Mega-Regionals: Can Hype Become Reality?

Recently, the negotiations for two very large RTAs, the TPP and the T-TIP, have invited much attention. They have been dubbed "megaregionals" due to their scope, ambition, and coverage of existing global 
trade. These two RTAs could prove to be a game-changer if they succeed in establishing two large blocs with the US at the center and the BRICS group outside.

While a case can be made for these mega-regionals, particularly in view of the DDA's long impasse and the inherent difficulty of moving forward multilaterally under the WTO-with 160 odd members at very different levels of development and with different capacities and interests-the TPP and T-TIP can also be viewed as a strategic response by the US and the EU, respectively, to the growing clout of BRICS, particularly China. These agreements may be an effort to counter the country's geopolitical rise where it can be expected to start asserting leadership of the global trading system. Hence, both the US and EU may be moving to secure their access to key markets and regions. ${ }^{11}$

The ongoing TPP negotiations are among a number of East Asian, North American, and South American countries. In 2006, Brunei, Chile, New Zealand, and Singapore initiated negotiations for an FTA (the Pacific 4) to achieve comprehensive trade liberalization by 2015 . Five additional countries - the US, Australia, Malaysia, Peru, and Vietnamjoined later, which led to the creation of the TPP. Three more, Mexico, Canada, and Japan, began participating in the negotiations in 2013 after the existing members had approved their participation. The group is, therefore, now often referred to as the TPP-12 (Cheong, 2013). The TPP negotiations aim to achieve the extensive liberalization of trade in goods and services as well as comprehensive development of rules and liberalization in areas such as investment, government procurement, nontariff measures, and intellectual property (Williams, 2013).

The TPP members are significantly diverse in terms of production structures, prosperity, capacity, and levels of economic development. This economic, cultural, and political diversity will necessitate long and difficult negotiations for members to reach their goal of extensive and comprehensive liberalization. Additionally, they will have to reconcile the TPP process with ongoing negotiations for other RTAs, e.g., the Regional Comprehensive Economic Partnership. These complexities have delayed the finalization of the TPP negotiations. Originally slated for

${ }^{11}$ Arguably, China and other major developing economies in the Asia-Pacific are responding with their own initiative, the Regional Comprehensive Economic Partnership, which aims to conclude an FTA among the ten ASEAN members and their partners (Australia, China, India, Japan, the Republic of Korea, and New Zealand) by 2015. 
conclusion by end-2012, the deadline was extended to end-2013. This, too, was missed. Perhaps, as a result, TPP members now refrain from setting a firm deadline although the US has indicated its intention to push for the completion of these negotiations by end-2014.

One argument is that, since the goods trade among TPP members amounted to a staggering US\$ 2 trillion in 2012, the agreement will have a significant impact on global trade dynamics. However, it may not be as significant as the numbers suggest, mainly for two reasons. First, the bulk of this goods trade is among only four members: the US, Canada and Mexico (NAFTA), and Japan. Intra-NAFTA trade alone amounted to nearly US\$1.2 trillion in 2012 and bilateral trade between Japan and NAFTA accounted for another US\$ 250 billion. On the other hand, trade flows among the other TPP members accounted for only US $\$ 180$ billion of total TPP trade in 2012. Second, and as mentioned earlier, the numerous FTAs already in force among the Asia-Pacific countries (almost 100 bilateral and multilateral RTAs) may further liberalize the goods trade under the TPP only to a small extent.

The T-TIP negotiations between the US and the EU also aim for a far-reaching trade agreement, including tariff reductions, the liberalization of behind-the-border and other nontariff barriers, and the possible harmonization of regulations and standards governing the services, investment, and public procurement markets (European Commission, 2014). Launched in 2013, the negotiations are still at an early stage, although the parties have indicated their desire to conclude the agreement soon.

Given the currently low tariff levels on trans-Atlantic trade, Fontagné, Gourdon, and Jean (2013) estimate that the average tariff protection on EU goods imported by the US amounts to only 2.2 percent, while US goods imported by the EU attract an average tariff duty of 3.3 percent in ad valorem-equivalent terms. More significant gains are expected by eliminating nontariff measures and harmonizing the standards that act as barriers to trade, investment, and public procurement.

Fontagné et al. (2013) estimate that bilateral ad valoremequivalent protection between the US and the EU from nontariff measures range between 19 and 73 percent across agriculture, manufacturing, and services. However, eliminating nontariff barriers that often relate to other public policy objectives-such as health, safety, and 
environment-and harmonizing regulations emanating from rather different perspectives on the role and reach of public policy on either side of the Atlantic will not be easy. The T-TIP negotiations have attracted a great deal of public attention, anxiety, and some criticism from public interest groups both in the US and the EU. This could mean slow and difficult negotiations and uncertain outcomes.

Given the intended immense breadth, depth, and coverage of the proposed TPP and T-TIP, these mega-regionals could have a significant impact on the trade of nonmembers, particularly LDCs and low-income countries (LICs) that currently enjoy substantial benefits under PTAs with major TPP and T-TIP members and/or are not part of other dynamic RTAs. However, the extent of this impact will depend on two key factors: (i) the existing levels and structure of trade between these countries and members of the TPP and T-TIP, and (ii) the level of liberalization and regulatory harmonization achieved under the TPP and T-TIP.

The implementation of the TPP and T-TIP could affect LDCs and LICs in two ways. The first will be their direct effect on these countries' existing access to EU and US markets on preferential terms under their PTAs. The second will be the impact of the reduction of nontariff measures and harmonization of standards under the TPP and T-TIP, which may increase or reduce export costs for LDCs and LICs. ${ }^{12}$

Studies differ, however, in their assessment of the impact of the TPP and T-TIP on nonmembers. Cheong (2013) finds that the implementation of the TPP will result in a 0.07 percent reduction in the rest of the world's GDP. Petri and Plummer (2012) of the Peterson Institute provide similar estimates: a 0.07 percent reduction in the rest of the world's GDP by 2025 (which includes the potential impact of liberalizing nontariff measures). Against these fairly small negative impacts, the Bertelsmann Institute indicates that the T-TIP could have much larger negative impacts for many developing countries and LICs (Felbermayr, Heid, \& Lehwald, 2013). These estimates look at the negative impacts of tariff liberalization alone as well as at a deeper

\footnotetext{
${ }^{12}$ Standards reforms under the TPP and T-TIP (through harmonization, equivalence, and/or mutual recognition) could have a positive or negative impact on nonmembers. The negative impact will occur if standards and regulations are made stricter, increasing the cost of compliance for nonmembers. On the other hand, the impact may be positive if nonmembers are allowed to comply with a single set of standards to gain access to the entire TPP or T-TIP markets, thus lowering the cost of compliance. The net impact on nonmembers will depend on both the stringency of the new measures as well as the degree of harmonization of standards across the TPP and T-TIP.
} 
liberalization scenario. Under the first, the real per capita income of an individual developing country is estimated to change by between 0.5 and -7.4 percent; under the second, the estimated change is between -0.1 and -7.2 percent. This will occur mainly due to preference erosion and trade diversion away from developing countries.

On the other hand, a study commissioned by the EU finds that LICs would gain from the establishment of the T-TIP. Their GDPs would rise by 0.09 and 0.2 percent, respectively, under the less ambitious and more ambitious scenarios. However, this positive impact is due mainly to the positive spillover effects of the "streamlining of EU and US regulations in the process of negotiations and convergence of EU-US standards" and the "scope for some resulting convergence in global standards and cross-recognition" of standards. Nonetheless, these spillovers will depend greatly on the extent to which the T-TIP results in regulatory reforms and harmonization (Francois et al., 2013).

Generally speaking, LDCs and LICs will face substantial preference erosion and stronger competition if their exports to some or all TPP and TTIP countries are similar to those traded among TPP and T-TIP countries. For example, the participation of Vietnam in the TPP is expected to have a significant impact on textile and apparel producers from non-TPP countries who currently enjoy preferential access to the US market under various PTAs. Similarly, Rollo et al. (2013) indicate that exports of textiles, clothing and footwear, and specific agricultural products such as fish, bananas, and sugar from developing countries will suffer preference erosion in both the EU and US markets once the T-TIP is implemented.

The above discussion shows that, while the overall global effects of the TPP and T-TIP might be small, certain developing countries will likely face stiffer export competition in specific products in the liberalized TPP and T-TIP markets, particularly the US and the EU. Table 1 summarizes the negative impacts of T-TIP implementation on LDCs and developing countries. Not surprisingly, Pakistan is on the list.

Two further points are in order here, particularly keeping in mind that the US is at the center of both the TPP and T-TIP. First, US trade policy interests are, arguably, a major force behind the politics and substance of these negotiations. However, in both agreements, the US faces strong negotiating partners, especially in the case of the T-TIP. Even the TPP involves a number of advanced industrialized countries as well as a small, but strong, group of developing countries with sound political and technical capacities. 
Second, there are formidable domestic political economy constraints facing many TPP and T-TIP countries. This is clearly the case for the US: the Obama administration's commitment to trade and investment liberalization is generally lukewarm and subject to strong opposition even within the Democrats; this could hamper attempts to persuade the much-needed Trade Promotion Authority to negotiate with greater strength with the other trading partners. As a result, the TPP and T-TIP negotiations might yield much more modest agreements.

Table 1: LICs vulnerable to negative impacts from T-TIP

\begin{tabular}{|c|c|c|c|}
\hline & & & Based on nonfuel exports \\
\hline Market & $\begin{array}{l}5 \text { or more of the top } 20 \\
\text { export products have } \\
\text { MFN } 10 \%<\text { tariff }<15 \%\end{array}$ & $\begin{array}{l}1 \text { or more of the top } 20 \\
\text { export products have } \\
\text { MFN tariff }>15 \%\end{array}$ & $\begin{array}{c}10 \text { or more of the top } 20 \\
\text { export products are } \\
\text { exposed to SPS }\end{array}$ \\
\hline EU & $\begin{array}{l}\text { Bangladesh, Pakistan, } \\
\text { Cambodia, Haiti, } \\
\text { Mauritania, Madagascar, } \\
\text { Nepal }\end{array}$ & $\begin{array}{l}\text { Cambodia, Ghana, } \\
\text { Chad, Burundi, } \\
\text { Madagascar, Malawi, } \\
\text { Togo }\end{array}$ & $\begin{array}{l}\text { Ghana, Kenya, } \\
\text { Mauritania, Burkina } \\
\text { Faso, Burundi, DR } \\
\text { Congo, the Gambia, } \\
\text { Occupied Palestine } \\
\text { Territories, Rwanda, } \\
\text { Somalia, Sudan, Uganda }\end{array}$ \\
\hline US & $\begin{array}{l}\text { Bangladesh, Pakistan, } \\
\text { Cambodia, Haiti, Kenya, } \\
\text { Madagascar }\end{array}$ & $\begin{array}{l}\text { Bangladesh, Pakistan, } \\
\text { Cambodia, Haiti, Kenya, } \\
\text { Ethiopia, Guinea, } \\
\text { Burkina Faso, Kyrgyz } \\
\text { Republic, Madagascar, } \\
\text { Malawi, Mali, } \\
\text { Mozambique, Occupied } \\
\text { Palestine Territories, } \\
\text { Rwanda, Togo, Uganda }\end{array}$ & $\begin{array}{l}\text { Ghana, Nigeria, Malawi, } \\
\text { Togo, Uganda }\end{array}$ \\
\hline
\end{tabular}

Source: Rollo et al. (2013).

\section{Pakistan in a World of RTAs and PTAs: Performance and Proposals}

This section examines the role of Pakistan in various RTAs and PTAs relative to other countries, and presents some recommendations that could help the country protect and expand its trade benefits.

\subsection{Pakistan in RTAs: A Marginal Player}

Pakistan's RTA activity began with its entering the Protocol on Trade Negotiations in 1973, which led to the Global System of Trade Preferences-a plurilateral trade liberalization arrangement only among developing countries under the auspices of UNCTAD. This was followed 
by the Economic Cooperation Organization (ECO) and the South Asian Preferential Trade Agreement (SAPTA) in the 1990s. Since then, Pakistan has joined the South Asian Free Trade Agreement (SAFTA)-in force since 2006 - and signed three bilateral RTAs with Malaysia, Sri Lanka, and China, respectively. It has also signed PSAs with Iran, Mauritius, and Indonesia.

As Figure 14 shows, Pakistan's situation is substantially different from that of the major trading countries, not only in terms of the fewer RTAs it has signed, but also by their limited scope. Half its RTAs are PSAs and the country is not part of any CU. Admittedly, Pakistan has a very limited number of RTAs, but its performance needs to be viewed in the context of a comparable peer group of countries.

Figure 14: Types of RTAs: Pakistan vs. major trading economies

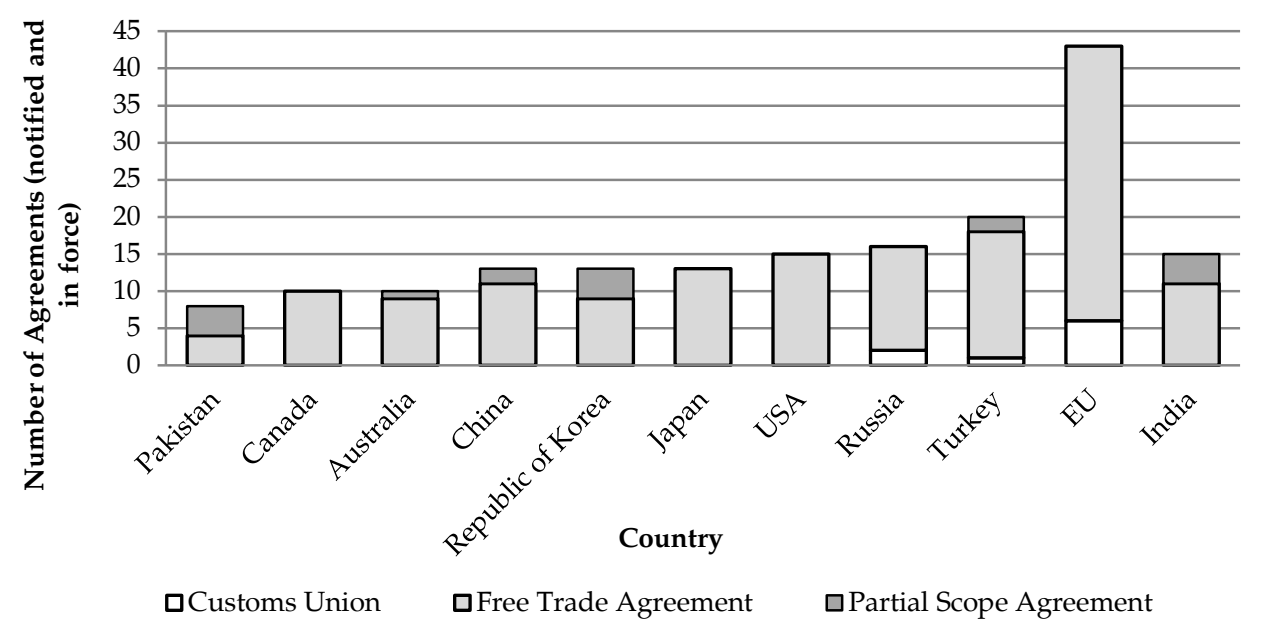

It is tempting to look toward the SAARC countries as the most appropriate peer group for Pakistan. Figure 15 shows that, in terms of RTA membership, Pakistan ranks higher than all the other SAARC countries except India. However, this is misleading because five of the eight SAARC members are LDCs and thus benefit from nonreciprocal PTAs. They would not have much incentive to join an RTA, which would require them to offer reciprocal trade concessions. 
Figure 15: RTA membership of SAARC countries

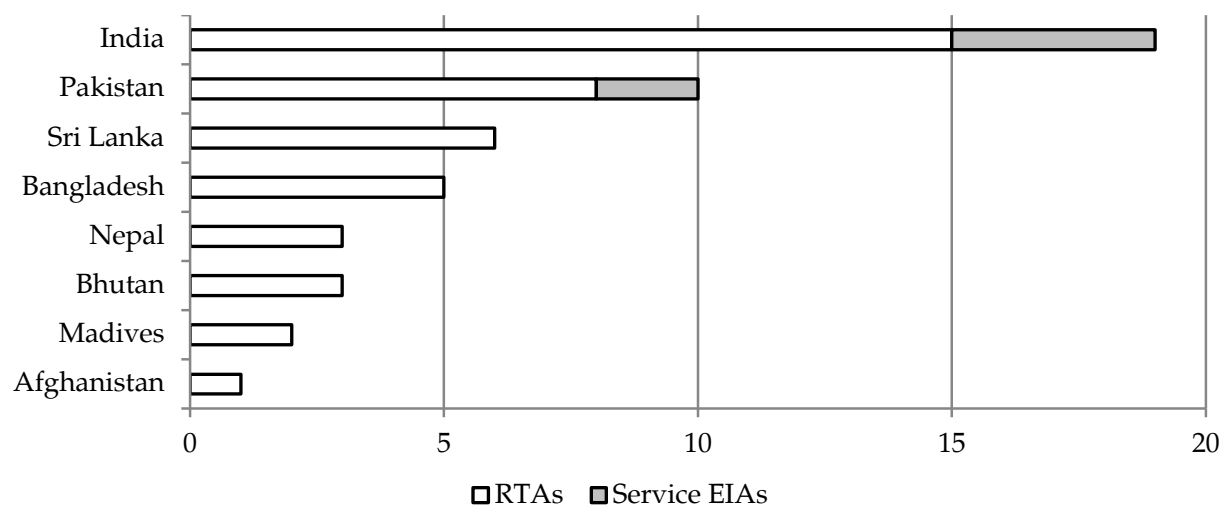

One can construct another peer group for Pakistan by identifying all those countries (excluding LDCs that benefit from PTAs) that belong to fewer than ten RTAs. Figure 16 shows that these are predominantly from the Middle East and North Africa, parts of Latin America, Central Asia, and sub-Saharan Africa. Most of the countries in this group are not considered dynamic economies, with the notable exception of Argentina and Brazil. It is, therefore, a matter of concern that Pakistan should fall within this group. Arguably, Pakistan should aim to move away from this group by strategically joining more RTAs with economies that are more dynamic.

Figure 16: Countries with fewer than ten RTAs

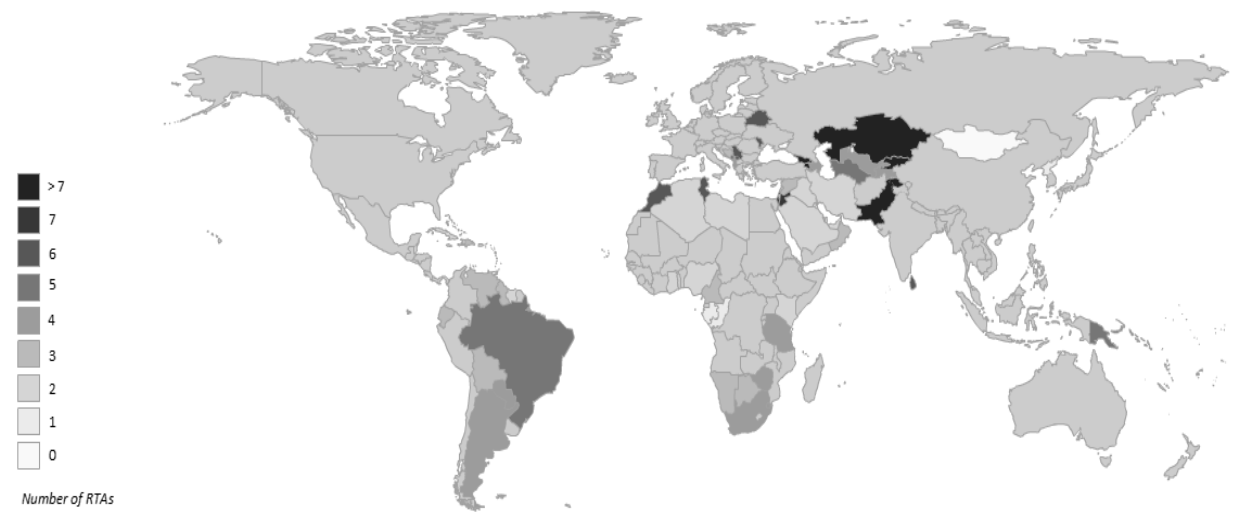

Its relatively small RTA membership aside, the volume of trade between Pakistan and its RTA/FTA partners is fairly limited (see Table 2 ), barring trade with China. This raises questions concerning the 
relevance, additional utility, structure, and coverage of these agreements. Pakistan is reportedly at various stages of FTA talks, or preparations for talks, with many countries-Brunei, Canada, Indonesia, Jordan, Morocco, Nepal, Russia, Singapore, Switzerland, Turkey, and Thailand-as well as with the Gulf Cooperation Council. In 2006, it signed a framework agreement on trade with Mercosur. Moreover, there is mention of possible FTAs with Afghanistan, Algeria, the EU, Japan, Laos, Mexico, New Zealand, South Africa, and Tunisia. ${ }^{13}$

The list of countries with which Pakistan may soon conclude agreements indicates that, much like other developing countries, it has started to engage in agreements outside its immediate region. Its current PSAs and FTAs have been concluded predominantly with countries in Asia, e.g., SAFTA and Malaysia. Although RTA negotiations with other Asian countries are underway (for example, with Singapore), Pakistan has also indicated an interest in negotiating agreements with a number of countries in Europe, the Americas, and Africa.

Table 2: Pakistan's RTAs with trade volumes

\begin{tabular}{llllll}
\hline & & \multicolumn{2}{c}{$\begin{array}{c}\text { \% of Pakistan's total } \\
\text { trade }\end{array}$} & \multicolumn{3}{c}{\begin{tabular}{c} 
Imports as \% of exports \\
\cline { 3 - 6 }
\end{tabular}} & $\begin{array}{c}\text { Year of } \\
\text { entry into } \\
\text { force }\end{array}$ & $\begin{array}{c}\text { One year } \\
\text { before entry } \\
\text { into force }\end{array}$ & $\begin{array}{c}\text { Latest } \\
\mathbf{( 2 0 1 2 )}\end{array}$ & $\begin{array}{c}\text { Onear } \\
\text { before entry } \\
\text { into force }\end{array}$ & $\begin{array}{c}\text { Latest } \\
\mathbf{( 2 0 1 2 )}\end{array}$ \\
\hline ECO & 1992 & $\mathrm{n} / \mathrm{a}$ & 4.75 & $\mathrm{n} / \mathrm{a}$ & 21.09 \\
SAARC & 2006 & 4.31 & 4.49 & 177.20 & 127.03 \\
China & 2007 & 7.32 & 13.6 & 575.34 & 255.26 \\
Malaysia & 2008 & 2.46 & 3.46 & $1,423.15$ & 913.14 \\
Sri Lanka & 2005 & 0.58 & 0.56 & 33.89 & 27.72 \\
Iran (PSA) & 2004 & 1.54 & 0.38 & 367.43 & 84.77 \\
Mauritius (PSA) & 2007 & 0.08 & 0.05 & 3.39 & 32.44 \\
Indonesia (PSA) & 2013 & In force 2013 & 2.32 & In force 2013 & 571.81 \\
\hline
\end{tabular}

Source: http://www.intracen.org/itc/market-info-tools/trade-statistics/

\subsection{Pakistan in PTAs: Losing Out to LDCs}

Of the PTAs in which Pakistan participates, the GSP offered by the EU stands out. The benefits to Pakistan under this scheme increased

\footnotetext{
${ }^{13}$ This information is from www.bilateral.org. However, it is based largely on media reports and could not be verified by other sources.
} 
somewhat when the EU decided to offer the country special trade preferences in view of the unprecedented devastation caused by the 2010 floods. To do this, the EU needed a waiver from the WTO allowing it to offer additional benefits exclusively to Pakistan and not to other developing countries under its GSP. The EU also encountered some opposition from member countries apprehensive about the impact of increased Pakistani exports of textiles and apparel. Both factors reduced the number of products that would have benefitted from additional tariff preferences and also delayed the finalization and implementation of the scheme.

More significant is the fact that Pakistan has become eligible for the EU's GSP-plus scheme, which offers additional benefits that reward the beneficiary country for its performance toward achieving the goals of "sustainable development" and "good governance." This could give Pakistan a competitive edge, given that its major competitors, particularly in textiles and clothing (China, Colombia, India, Indonesia, Thailand, and Vietnam), are not yet eligible for the EU's GSP-plus scheme. ${ }^{14}$

While some Pakistani products were already being exported on a duty-free basis under most-favored nation status, the standard GSP, or the Special Trade Preferences Scheme for Pakistan, the GSP-plus will enable Pakistan to export many more of its products on this basis. The textiles and garments sector is expected to benefit the most: Pakistani trade analysts have projected an overall growth rate of 15 percent for the sector in 2014/15. However, remaining eligible for the GSP-plus will depend on whether Pakistan commits to the implementation of 27 core international conventions concerning human rights, labor rights, environment, narcotics control, and corruption. In essence, what the country requires to continue to benefit from the projected economic gains of the GSP-plus is political will and resources from public and private stakeholders to ensure continued adherence to/implementation of these core conventions.

Three of Pakistan's fellow SAARC members-Afghanistan, Bangladesh, and Nepal-are, as LDCs, among the top PTA beneficiaries globally and have an edge over Pakistan in terms of access to major markets. India, while still a PTA beneficiary, although less so than Pakistan, has also become a provider of PTAs to LDCs. In the competition

\footnotetext{
${ }^{14}$ China has graduated out of the "textiles" and "garments" sections of the EU's GSP scheme, while India has moved out of the "garments" section.
} 
to benefit from PTAs, therefore, it is the LDCs within and outside the region that Pakistan must take into account.

\subsection{The Way Forward: Recommendations for the Short and Medium Terms}

With the WTO moving very slowly on one hand and various forms of discriminatory international trading arrangements expanding on the other, countries such as Pakistan face a difficult situation. Its main interests lie in the multilateral trading system because it is not part of many RTAs and its nonreciprocal preferential access to major markets is limited. There are no quick fixes and the factors driving RTAs and PTAs are beyond Pakistan's control. However, it cannot afford to remain idle. Some policy suggestions are, therefore, described below.

While remaining actively engaged with the WTO, Pakistan should consider pursuing several lines of action related to RTAs and PTAs in the short and medium term. In the short term, it should aim to maintain and, where possible, increase its market access opportunities. This will require two-pronged action. First, Pakistan should continue to strengthen current initiatives to negotiate RTAs, either bilateral or plurilateral, with selected countries within the region and outside. This should include both the socalled "dynamic countries" (mostly in the Asia-Pacific) that are at the forefront of RTA activity, as well as countries in a situation similar to Pakistan (e.g., in Latin America, Central Asia, and the Middle East). This initiative will have important spillover effects in building the technical, human, and institutional capacity of Pakistan in the area of RTA negotiations and in improving its visibility on the RTA landscape.

Second, Pakistan should aggressively defend and, where possible, expand its benefits under PTAs. While the LDCs clearly have an edge in this area as the main beneficiaries of nonreciprocal preferential schemes, Pakistan should not give up on the GSP. Of particular interest are the GSP-plus schemes that offer better/greater market access based on a country's ability to meet additional criteria. Pakistan should actively seek these additional benefits wherever possible. It should also closely monitor the pattern of PTAs and not hesitate to challenge those in the WTO whose legal basis is doubtful and which have a detrimental effect on Pakistan. ${ }^{15}$

${ }^{15}$ For example, India successfully challenged the additional GSP benefits provided to Pakistan by the EU after 11 September 2001 under the so-called "Drug Arrangements" (see WTO, 2010). 
In the medium term, Pakistan's strategic trade interests lie in becoming part of dynamic RTAs, which are mostly in the Asia-Pacific, Europe, and North America. This will not be easy: many existing members of these RTAs are not necessarily interested in trading with Pakistan. Moreover, large segments of Pakistan's economy may not be competitive enough to take advantage of market access opportunities in these RTAs. This is a formidable challenge and will require Pakistan to improve its competitiveness in agriculture, industry, and services. Key efforts will include substantial and sustained investments in infrastructure, energy, and human resources; improving law and order; and adopting a coherent and supportive macroeconomic framework. 


\section{References}

Cheong, I. (2013). Negotiations for the Trans-Pacific Partnership Agreement: Evaluation and implications for East Asian regionalism (Working Paper No. 428). Tokyo: Asian Development Bank Institute.

European Commission. (2014). In focus: The Transatlantic Trade and Investment Partnership [Webpage]. Available at http:/ / ec.europa.eu/trade/policy/in-focus/T-TIP/

Felbermayr, G., Heid, B., \& Lehwald, S. (2013). Transatlantic Trade and Investment Partnership (TTIP): Who benefits from a free trade deal? Gütersloh, Germany: Bertelsmann Stiftung.

Fontagné, L., Gourdon, J., \& Jean, S. (2013). Transatlantic trade: Whither partnership, which economic consequences? (Policy Brief No. 1). Paris: Centre d'Etudes Prospectives et d'Informations Internationales.

Francois, J., Manchin, M., Norberg, H., Pindyuk, O., \& Tomberger, P. (2013). Reducing Transatlantic barriers to trade and investment: An economic assessment. London: Centre for Economic Policy Research.

International Trade Centre. (n.d.). Trade statistics [Database]. Available at http://www.intracen.org/itc/market-info-tools/trade-statistics/

Petri, P. A., \& Plummer, M. G. (2012). The Trans-Pacific Partnership and Asia-Pacific integration: Policy implications. Washington, DC: Peterson Institute for International Economics.

Rollo, J., Holmes, P., Henson, S., Mendez Parra, M., Ollerenshaw, S., Lopez Gonzalez, J., ... Sandi, M. (2013). Potential effects of the proposed Transatlantic Trade and Investment Partnership on selected developing countries. Brighton: Institute of Development Studies, InterAnalysis Ltd., and ITEAS Consulting.

Williams, B. R. (2013). Trans-Pacific Partnership (TPP) countries: Comparative trade and economic analysis. Washington, DC: Congressional Research Service.

World Trade Organization. (2010). Dispute settlement: Dispute DS246: European Communities - Conditions for the granting of tariff preferences to developing countries. Retrieved from http://www.wto.org/english/tratop_e/dispu_e/cases_e/1pages um_e/ds246sum_e.pdf 
World Trade Organization. (2014). WTO | Regional trade agreements [Database]. Available at http://rtais.wto.org/UI/PublicMaintainRTAHome.aspx

World Trade Organization. (n.d.). WTO | Preferential trade arrangements [Database]. Available at http://ptadb.wto.org 